\title{
A CKNOWLEDGMENTS
}

For support given to my work I should like to express my gratitude to the following institutions and persons:

The Fundação Calouste Gulbenkian of Lisbon, Portugal, and Ambassador Teotónio Pereira and Dr. J. Braga de Oliveira for the generous aid they gave me to do field work in Portugal during the summer of 1965.

The Comissão de Viticultura da Região dos Vinhos Verdes of Pôrto and President António Costa Leme, Eng ${ }^{0}$ Amândio Barbedo Galhano, and Eng ${ }^{\circ}$ Manuel Babo for their consideration and aid.

The Instituto do Vinho do Pôrto for its aid on numerous occasions, and especially to Sr. António Sarmento de Vasconcellos.

The Federação dos Vinicultores da Região do Douro (Casa do Douro) for statistical information and advice.

The Federação dos Vinicultores do Dão in Viseu and Dr. Tavares de Pina and Eng ${ }^{0}$ Albino Fernandes Correia, who took time from their busy days to instruct me as to conditions of their region.

The Junta Nacional do Vinho, President Eng ${ }^{0}$ Fernando Santos e Castro, and $\mathrm{Eng}^{\circ}$ Virgilio Dantas for great help in many ways during the period of my work in Lisbon.

Various departments of the University of Arizona: the office of the Coordinator of Research, and Dr. David Patrick and Dr. Edward Wise for the grant in support of necessary cartography; to the College of Business and Public Administration and Dean William Voris for making time available for writing the manuscript; to the Division of Research and Dr. David Shirley for arranging to have the manuscript typed.

My wife for reading and improving the manuscript by her suggestions. 
THIS PAGE INTENTIONALLY LEFT BLANK 